\title{
Porosity of expanded clay manufactured with addition of sludge from the brewing industry
}

\author{
Carmen Martínez García • Teresa Cotes Palomino • \\ Francisco J. Iglesias Godino · Francisco A. Corpas Iglesias
}

Received: 28 September 2013/ Accepted: 29 April 2014/Published online: 2 August 2014

(C) The Author(s) 2014. This article is published with open access at Springerlink.com

\begin{abstract}
This study describes the industrial use of waste generated from the brewing industry, specifically sludge from a wastewater treatment plant. The processing technique was developed to produce ceramic material with the potential for use as a lightweight aggregate in construction. This waste is usually dumped in landfills, but the current increase in restrictions on dumping and interest in improving the environment make our proposal for gaining value from this sludge a significant contribution. The chemical composition of the raw materials was analyzed (using X-ray fluorescence and elemental analysis) and their thermal behavior evaluated (thermogravimetric analysis and differential thermal analysis). To determine the effect of adding sludge to the aggregate, different compositions were then prepared and tested. To obtain the material's final resistance and cohesion, the dried sample was subjected to a firing process in a kiln. The samples were prepared without special pre-treatment steps, such as milling, and without the addition of expansive additive. The new aggregate has a low bulk density, due to the formation of an internal cellular structure, a porous internal and a partially vitrified
\end{abstract}

\footnotetext{
C. M. García ( $ه)$ · T. C. Palomino · F. J. I. Godino • F. A. C. Iglesias

Department of Chemical, Environmental and Materials Engineering, E.P.S. Linares, University of Jaen, C/Alfonso X, el Sabio, 28, 23700 Linares, Jaén, Spain

e-mail: cmartin@ujaen.es

T. C. Palomino

e-mail: mtcotes@ujaen.es

F. J. I. Godino

e-mail: figodino@ujaen.es

F. A. C. Iglesias

e-mail: facorpas@ujaen.es
}

external shell. As waste is added, water absorption increases by values of $17-26 \%$, as does the porosity, resulting in a linear relationship between the pore volume and percentage of sludge added.

Keywords Sludge $\cdot$ Lightweight aggregate $\cdot$ Waste reuse

\section{Introduction}

European legislation encourages the development of a variety of ceramic building materials, such as expanded aggregates, that incorporate waste. For example, the national integrated waste plan for 2007-2015 requires implementing not only measures to reduce generation of the waste, but also recycling and reuse at all levels. The technical building code (TBC) seeks to respond to social demand to improve the quality of construction, while also achieving better protection of the user and promotion of sustainable development. European policies such as the Lisbon and Göteborg Agendas also propose a sustainable development strategy that assumes responsibility for management of natural resources. Other technologies that have been developed successfully include using wastes such as fly ash, scrap tire rubber, and sludge from the paper industry in the production of lightweight concrete aggregates [1-3] and expanded clay [4] for structural applications. The use of waste has the advantage of both optimizing the properties of ceramic products and reducing cost and environmental problems involved in depositing this waste in landfills. It is currently estimated that industrial waste in Europe exceeds 900 million tonnes per year. Further, using this waste in ceramic building materials could help structures to obtain sustainable building certification. 
Lightweight aggregates (LWAs) are increasingly in demand, particularly in the precast concrete industry, where they are used in a range of construction products. The lighter weight of concrete components made with LWAs aids in off-site manufacturing has significant advantages, both during construction and throughout the life of the building [5]. Development of LWAs also fulfils the need for alternate waste disposal methods. Research into the economical reuse of various wastes published in recent years includes studies of the incorporation of these wastes in clay-based products [6]. Because the final LWA product varies in shape and size, and because production rates are very high, LWA production has the potential for high levels of incorporation. Further, research shows the reuse of several wastes in expanded clay-based formulations. These wastes include quarry minerals, industrial wastewater sludge, paper-pulp and wood or incinerator bottom ash, and pulverized fuel ash [7-14].

Various types of waste are being investigated for use in the manufacture of construction materials. These include sewage sludge waste, waste products in power generation processes and food industry remains [15-18]. The sludge is used as a partial replacement of clay, or in the manufacture of cement [19-22]. All studies to date have used $<30 \%$ sludge. Some authors have investigated the use of sludge in mortar and concrete [23-25]. Others propose lightweight aggregate (LWA) of sewage sludge and clay [26-30].

The manufacturing principle used is based on the occluded expansion undergone and the gases formed during treatment of a mass of clay mixed with waste when it is subjected to a temperature increase.

Firing is the most important stage in the ceramic process for the production of lightweight aggregate. It is during this phase that decomposition of the clay mineral reticle causes instability in the joint. This leads to the formation of amorphous phase, liquid at this temperature, which serves as a unifying element in the array. This phase will remain until the end of sintering, and some of it often creates very stable crystalline phases. During ceramization, the inorganic portion of the waste enters the amorphous phase of the ceramic matrix. All solid state reactions, as is the case of ceramics, have extremely slow reaction kinetics. The factor that can speed up the process is particle size. The finer the particle, the greater the surface area and the greater the reaction capacity. In contrast, a large enough particle will not react. When the goal is to inertize a waste due to its toxicity, the waste must be ground very fine. In this case, the waste melts partially and is integrated into the ceramic matrix. If the particle size is coarse, the waste particle does not interact with the ceramic matrix and is simply encapsulated [31, 32].

The thermal process for sintering conventional clay usually consists of constant and gradual increase in the temperature until the clay mass reaches approximately
950-1,000 ${ }^{\circ} \mathrm{C}$. The process is radically different for the formation of the expanded clay. Here, the temperature rise is very sharp so that the surface layer of clay vitrifies before ceramization of the inner layers begins. Vitrification of the outer layer prevents escape of the gases formed in the interior of the sample, forcing swelling.

This paper presents a study of incorporating sludge from a treatment plant for wastewater from the brewing industry to produce expanded-clay LWA for use in the construction industry. It also studies the effect that adding these residues has on the porosity of the materials produced. This process has valuable potential for turning a waste into an alternate raw material, thereby helping to reduce the quantity of waste disposal in landfill and its subsequent impacts.

\section{Methods}

Raw materials

The raw materials used in this study are clay from the ceramics industry in the city of Bailén in the province of Jaén (Spain), sludge from treatment plant for wastewater from the brewing industry, and water from the general utility network.

Because the clay received in the laboratory had a very heterogeneous grain size, it was subjected to milling in a hammer mill. If the clay is shaped by pressure, it must subsequently be passed through a $0.45 \mathrm{~mm}$ sieve. Control of the particle size is important, as it influences the physical and mechanical characteristics of the final product.

The sludge from brewing industry was collected at the plant and transported to the laboratory. This waste was dried in an oven at $90{ }^{\circ} \mathrm{C}$ for $24 \mathrm{~h}$ to reduce the high initial moisture content. When dry, the waste was subjected to grinding in a hammer mill. The resulting substance was subsequently transferred to an agate ball mill and sieved to obtain the proper grain size.

Preparation of samples

To determine the effect of adding the sludge, we used different quantities, from 0 to $15 \%$ of the sample mass. The appropriate quantities of dry waste and clay were weighed and then mixed thoroughly in a porcelain mortar. The samples were shaped by hand. Water was added during this process (20\% in mass) to obtain appropriate plasticity. Once the pieces were shaped, measured and weighed, they were dried at $110^{\circ} \mathrm{C}$ for $48 \mathrm{~h}$ to reduce their moisture content. As the drying progressed, the particles came closer together, and contraction increased [33].

To produce the final resistance and cohesion of the material, the dried samples were subjected to a firing 
process in a kiln that caused sintering of the grains and change in their density and porosity. More specifically, the dry samples were heated in a laboratory kiln until they reached $950{ }^{\circ} \mathrm{C}$. This temperature was then maintained for $1 \mathrm{~h}$, after which the samples were allowed to cool through natural convection after the kiln was turned off. The heating rate in the kiln was $10{ }^{\circ} \mathrm{C} / \mathrm{min}$.

Tests performed on the raw materials

The raw materials were tested to determine their physical and chemical characteristics, as follows:

The total carbon, hydrogen, nitrogen and sulphur content were determined by combustion of the samples in an $\mathrm{O}_{2}$ atmosphere using the CHNS-O Thermo Finnigan Elementary Analyzer Flash EA 1112, Milan, Italy.

The organic matter content was determined by firing the samples in an oven at $550{ }^{\circ} \mathrm{C}$ for $12 \mathrm{~h}$.

The higher heating value (HHV) was determined using a Parr 1341 Plain Oxygen Bomb Calorimeter, according to the UNE 32 006:1995 standard [34, 35]. The calorific value of a fuel is the energy released per unit of weight by combustion with oxygen. Following the procedure indicated, we introduced eight dry samples of each type into the calorimetric pump and obtained the higher heating value (HHV). From this value, we obtained the lower heating values (LHV).

For the thermogravimetric analysis (TGA) and differential thermal analysis (DTA), we used a Mettler Toledo $850 \mathrm{e}$ balance. Samples of $40-60 \mathrm{mg}$ were placed in a platinum crucible and heated at a rate of $10{ }^{\circ} \mathrm{C} / \mathrm{min}$ from room temperature to $1,000{ }^{\circ} \mathrm{C}$. The data show the percentage weight losses based on temperature and the DTA diagram simultaneously.

Tests performed on the sintered materials

The physical properties for the sintered materials were determined as follows:

Weight loss from sintering was obtained by weighing the shaped piece after firing at $950{ }^{\circ} \mathrm{C}$ and subtracting the weight after the firing stage from the weight after the drying stage at $110{ }^{\circ} \mathrm{C}$.

The absolute density was determined using a gas $(\mathrm{He})$ displacement pycnometry system, Accupyc ${ }^{\mathrm{TM}}$ II 1340 by Micromeritics. Until recently, absolute density was determined using water or another liquid, which was expected to fill the pores in the sample and then removing their volume from measurement. The gas $(\mathrm{He})$ displacement pycnometry system, Accupyc ${ }^{\mathrm{TM}}$ II 1340 by Micromeritics is much more accurate and easier to use. It is faster than liquidbased techniques because the gases fill the pore spaces easily, quickly, and thoroughly.

Bulk density was determined by measuring the dry mass (md), immersed mass (mi) and $24 \mathrm{~h}$ saturated surface-dry mass (ms) of the samples. Particle bulk density was calculated using Archimedes' principle.

Water absorption capacity was measured using standard procedure UNE 67-027 [36].

The adsorption and desorption isotherms with $\mathrm{N}_{2}$ were determined and the distribution of mesoporosity analyzed following the BJH (Barrett, Joyner, and Halenda) method, using an ASAP 2020 accelerated surface area and porosymmetry system by Micromeritics. The following parameters were measured with the adsorption isotherm using the BET surface area method $\left(\mathrm{m}^{2} / \mathrm{g}\right)$, pore volume $\left(\mathrm{cm}^{3} / \mathrm{g}\right)$ and pore size $(\AA)$.

The microstructure of the samples was observed using scanning electron microscopy (SEM) with a high-resolution transmission electron microscope, JEOL SM 840. The samples were placed on an aluminium grate and coated with gold using an ion sputtering device JEOL JFC 1100.

\section{Results and discussion}

\section{Raw materials}

The results of elemental analysis of the $\mathrm{C}, \mathrm{H}, \mathrm{N}$ and $\mathrm{S}$ content in the clay and sludge are shown in Table 1.

The analysis shows that the sludge is $13.613 \%$ carbon. In addition, the organic matter content on ignition at $550{ }^{\circ} \mathrm{C}$ is determined to be $25.1 \%$. The mass loss during the interval of thermal analysis up to $500{ }^{\circ} \mathrm{C}$ is $71 \%$ of total mass and corresponds to the content of organic material in the sample. This result indicates that the waste will have high calorific value. The absence of sulphur in the sludge is also very significant, since it means that none of this waste will produce harmful sulphur oxides during combustion.

The averages are shown in Table 2. The wastewater sludge has a value of $4,181.7 \mathrm{~kJ} / \mathrm{kg}$. A value of this waste that can be added to the maximum percentage studied (15\% mass would thus provide $7 \%$ of the fuel needed in
Table 1 CNHS analysis of raw materials

\begin{tabular}{lrlllllll}
\hline & $\% \mathrm{C}$ & $\sigma \% \mathrm{C}$ & $\% \mathrm{H}$ & $\sigma \% \mathrm{H}$ & $\% \mathrm{~N}$ & $\sigma \% \mathrm{~N}$ & $\% \mathrm{~S}$ & $\sigma \% \mathrm{~S}$ \\
\hline Clay & 2.140 & 0.023 & 0.340 & 0.007 & 0.025 & 0.003 & 0.000 & - \\
Sludge & 13.613 & 0.192 & 1.973 & 0.022 & 1.807 & 0.046 & 0 & 0 \\
\hline
\end{tabular}


Table 2 Higher and lower heating values of sludge

\begin{tabular}{lllll}
\hline & HHV $(\mathrm{kJ} / \mathrm{kg})$ & $\sigma$ & LHV $(\mathrm{kJ} / \mathrm{kg})$ & $\sigma$ \\
\hline Wastewater sludge & $5,194.1$ & 7.9 & $4,181.7$ & 7.9 \\
\hline
\end{tabular}

manufacturing traditional brick [37-39]. Further, this waste is sulphur-free. These findings agree with those obtained in the elemental analysis and indicate a greater calorific contribution to the process. The results show that the waste can be used as fuel and thus save energy in the production process.

The results of the thermal analysis up to $1,000{ }^{\circ} \mathrm{C}$ for the clay can be seen in Fig. 1. We observe a small endothermic peak at $51.4{ }^{\circ} \mathrm{C}$, which can be attributed to moisture loss $(2 \%)$. As the temperature increases, weight loss increases. At $200{ }^{\circ} \mathrm{C}$, we observe another endothermic peak, higher than the first. During this reaction, the sample continues to lose weight, but not as sharply as during the first endothermic peak. Finally, in the interval from 600 to $900{ }^{\circ} \mathrm{C}$, a weight loss of $9.5 \%$ occurs, probably due to decomposition of $\mathrm{CaCO}_{3}$. We find a strong endothermic peak at $780{ }^{\circ} \mathrm{C}$.

The TGA-DTA curve of the sludge is similar to that of a solid fuel. The endothermic peak, which occurs at $150{ }^{\circ} \mathrm{C}$ and is associated with weight loss, is characteristic of released hygroscopic water. The exothermic peaks between $340-500{ }^{\circ} \mathrm{C}$ are probably attributable to elimination of structural water, as well as to elimination of the organic matter by combustion. The weight loss associated with these reactions is $3 \%$. The last endothermic peak, at $700{ }^{\circ} \mathrm{C}$, may be due to the decomposition of calcium carbonate (calcite). The total weight loss is $35 \mathrm{wt} \%$.

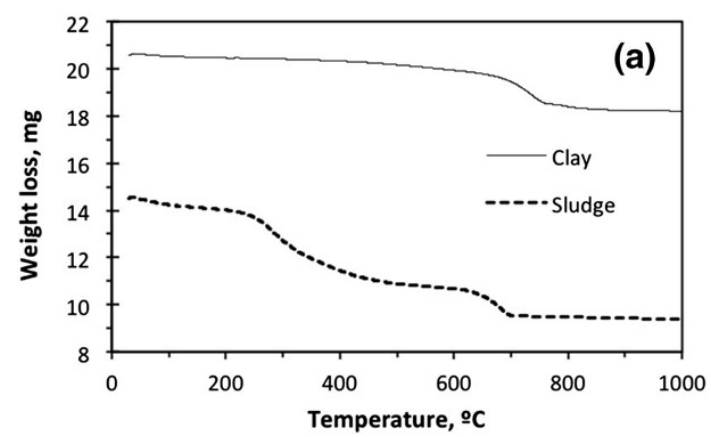

Fig. 1 TGA (a) and DTA (b) of clay and sludge
The results of the TGA analysis agree with the CNHS elemental analysis, which yields contents of carbon $(13.613 \%)$ and hydrogen $(1.973 \%)$ that explain the calorific value of this waste.

\section{Sintered materials}

The weight losses at the percentages studied are shown in Table 3. The results show that weight loss increases as the amount of waste increases. The sample with $15 \%$ mass of sludge has the greater weight loss. This change corresponds to the organic content of the waste. When the brick is sintered, varying weight loss is observed according to the percentage of sludge added, due probably to combustion of the organic matter as well as to moisture loss. For the sample with $0 \%$ mass of sludge, weight loss after firing at $950{ }^{\circ} \mathrm{C}$ is $9.74 \%$ and can be attributed mainly to organic matter content in the clay. With addition of sludge to the mixture, the weight loss increases, but only the mixture with the highest sludge content has greater weight loss on ignition than clay. Weight loss should increase due to the high contribution of organic loss from sludge.

Water absorption is shown in Fig. 2. Absorption values range from $17.75 \%$ (clay) to $26.04 \%$ (sample with $15 \%$ sludge). These results may be due to the lightening of residue, since its high organic matter content is consumed during combustion, generating a porous structure.

Ideally, water absorption of the lightweight aggregate should be as low as possible. Low absorption indicates a reduction in the volume of the water-accessible surface connected porosity. Since in many applications LWA is in frequent contact with the liquid in the environment, whether the surface of LWA absorbs water will depend on

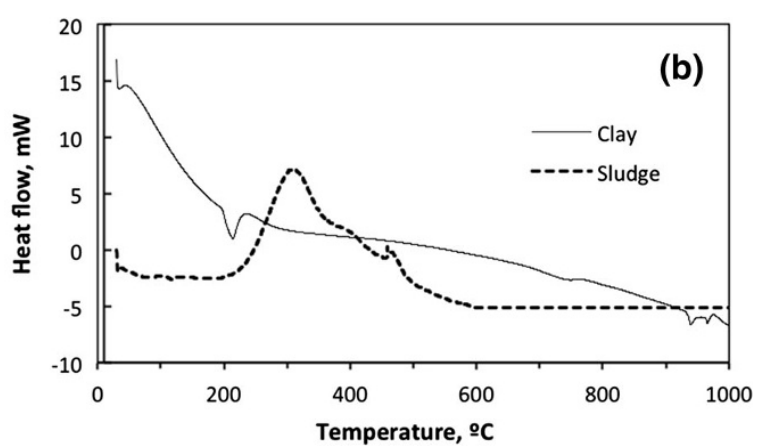

Table 3 Weight loss (\% mass) after sintering at $950{ }^{\circ} \mathrm{C}, 1 \mathrm{~h}$

\begin{tabular}{llllllll}
\hline$\%$ in mass waste & 0 & 2 & 4 & 6 & 8 & 10 & 12.5 \\
\hline Weight loss, \% sludge & $\mathbf{9 . 7 4}$ & 10.7 & 11.08 & 10.95 & 12.00 & 13.45 & 13.88 \\
\hline
\end{tabular}

The bold values show the maximun and minimun values 


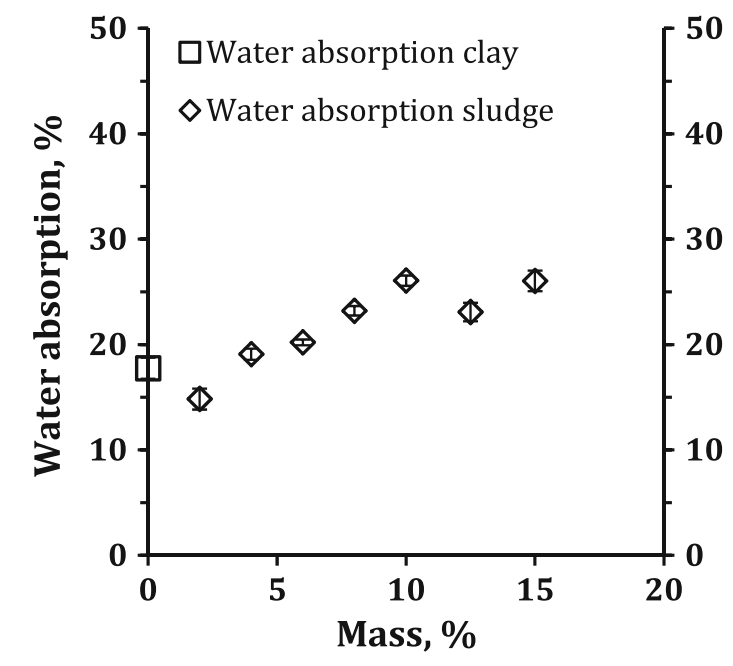

Fig. 2 Water absorption: clay and LWA with sludge

specific usage. At $950{ }^{\circ} \mathrm{C}$, the samples have significant interconnected open porosity and therefore high water absorption values for surfaces highly accessible to water. This mixture should be used, for example, when technological application of the aggregates involves laying with mortar. The higher the absorption, the greater the amount of moisture from the mortar that affects setting.

To clarify the relationship between water absorption and the microstructures of the LWA, the porous microstructures were then inspected using scanning electron microscopy (SEM). Sintering at $950{ }^{\circ} \mathrm{C}$ produced a fine granular material. Fracture occurred primarily between particles, and there is evidence of extensive intergranular connected porosity. This result agrees with the high water absorption data obtained. Figure 3 shows differences in the microstructure of the samples with a waste content of $0 \%$ and $15 \%$ in mass.

The absolute density (also termed the true, real, apparent, or skeletal density) is obtained when the volume measured
Table 4 Absolute and bulk density by LWA with wastewater sludge

\begin{tabular}{lllll}
\hline $\begin{array}{l}\text { \% Mass wastewater } \\
\text { sludge }\end{array}$ & $\begin{array}{l}\text { Absolute density } \\
\left(\mathrm{kg} / \mathrm{m}^{3}\right)\end{array}$ & $\sigma$ & $\begin{array}{l}\text { Bulk density } \\
\left(\mathrm{kg} / \mathrm{m}^{3}\right)\end{array}$ & $\sigma$ \\
\hline 0 & $2,699.6$ & 0.7 & $1,657.4$ & 0.3 \\
2 & $2,657.3$ & 0.1 & $1,756.8$ & 1.2 \\
8 & $2,554.7$ & 0.6 & $1,826.6$ & 0.9 \\
15 & $2,626.6$ & 0.6 & $1,396.0$ & 0.7 \\
\hline
\end{tabular}

excludes the pores as well as the void spaces between particles within the bulk sample. Table 4 shows the absolute density and the bulk density of the samples. The absolute density of the samples with residue is similar to the reference sample, since the absolute density of the voids or pores generated is not taken into account. The bulk density decreases at high percentages of residue, however, indicating connected porosity and water-accessible porosity.

Figure 4 shows the isotherms of adsorption and desorption for the samples with a waste content of 2,8 and $15 \%$ mass and indicates that the material has the forms typical of mesoporous material.

All cases correspond to the so-called Type IV isotherm, with its distinctive feature, the hysteresis loop. This loop is characteristic of solid, mesoporous materials with a pore size of 20-500 $\AA$ [40]. The results obtained in the isotherms also show that the samples are mesoporous, since high adsorption of the nitrogen half occurs at high pressures. The presence of hysteresis and increase in the amount of nitrogen absorbed at high pressures also indicate mesoporosity.

A solid real mesoporous sample, like that obtained in this study, is composed of an interconnected collection of pores of different shapes and sizes. In practice, none of ideal hysteresis cycles occurs. The real sample is thus a complex system, and precise description of this system has proven impossible to date. Most isotherm hysteresis cycle mesoporous materials can, however, be classified into four
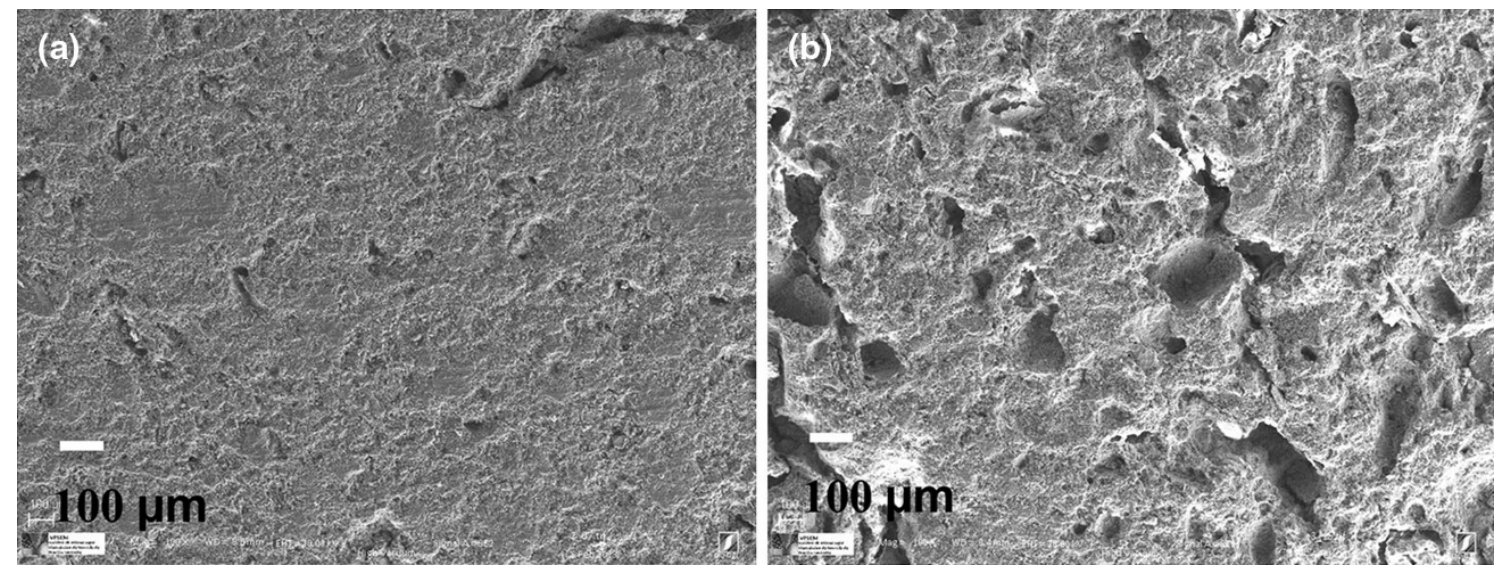

Fig. 3 SEM micrographs of clay sample (a) and sample containing 15 wt.\% of sludge (b) 

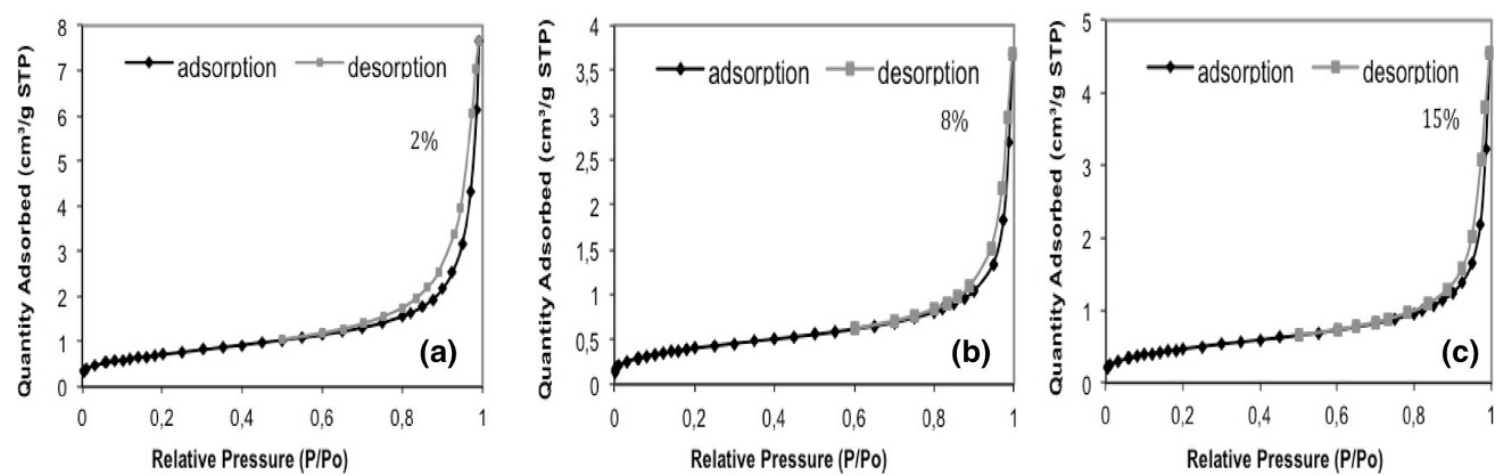

Fig. 4 Isotherm adsorption and desorption of LWA. Sludge content: a $2 \%$ mass; b $8 \%$ mass; $\mathbf{c} 15 \%$ mass

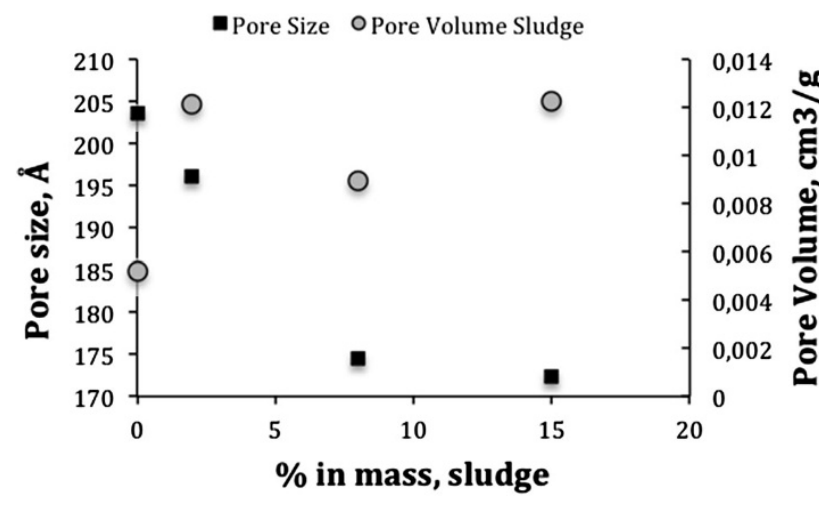

Fig. 5 Pore size and pore volume

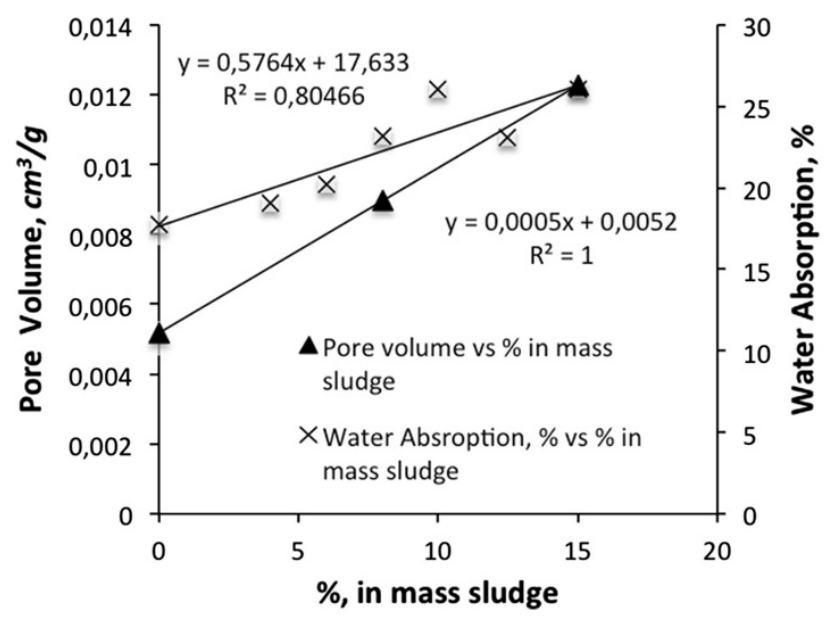

Fig. 6 Relationship between absorption and pore volume according to $\%$ mass of sludge

IUPAC categories, $\mathrm{H} 1, \mathrm{H} 2, \mathrm{H} 3$, and $\mathrm{H} 4$. Here, we are concerned with Type H3, a bond obtained when working with pores (slit-shaped) in agglomerates of parallel platelike particles.

The pore size is $205-170 \AA$, a size that characteristics of mesoporous materials. Figure 5 shows the reduction in pore size that occurs as the percentage of sludge increases.
The pore volume measured also increases considerably with the addition of waste. This increase is caused by the porosity generated in the thermal process due to the combustion of waste added.

These results agree with the absorption values presented above. There is also a linear relationship between these two variables as shown in Fig. 6.

Increasing the amount of residue increases the porosity inside the sample, which in turn increases water absorption.

\section{Conclusions}

This study investigated the properties of lightweight aggregates produced with clay and sludge from the brewing industry and sintered at $950{ }^{\circ} \mathrm{C}$. The following conclusions can be drawn from the experimental study. The results obtained show that adding brewing industry waste to LWA generally increases the water absorption and porosity of the samples prepared, making the LWA less dense and therefore more attractive for use as construction material. However, this increase in water absorption $(46 \%$ in the samples fabricated with clay only) may have negative effects when these construction materials are used, since they would absorb water that could impede setting of the mortar.

We conclude that using wastes in manufacturing LWA is a feasible option for principles of sustainable development.

Waste from the brewing industry can provide environmental and economic benefit, since some products currently considered waste could be used as raw material. Further, adding waste can save energy because the waste has a higher heating value.

The results enable us to conclude that there is a linear relationship between the quantities of residue used and increased water absorption.

Acknowledgments The authors thank Arcilla Bailén, S.L. of Bailén, Jaén (Spain) for supplying the clay and the Technical Research Services of the UJA and UMA for help in determining some properties. 
Conflict of interest The authors declare that they have no competing interests.

Authors' Contribution All authors drafted, readed and approved the final manuscript.

Open Access This article is distributed under the terms of the Creative Commons Attribution License which permits any use, distribution, and reproduction in any medium, provided the original author(s) and the source are credited.

\section{References}

1. Kayali, O., Zhu, B.: Chloride induced reinforcement corrosion in lightweight aggregate high strength fly ash concrete. Constr Build Mater 19, 327-336 (2005)

2. Choi, Y.-M., Moon, D.-J., Chung, J.-S., Cho, S.-K.: Effects of waste PET bottles aggregate on the properties of concrete. Cem Concr Res 35, 776-781 (2005)

3. Pierce, E., Blackwell, C.: Potential of scrap tire rubber as lightweight aggregate in flowable fill. Waste Manag 23, 197-208 (2003)

4. Pinto, S.: Valorização de resíduos da indústria da celulose na produção de agregados leve. Masteŕs thesis. Universidade de Aveiro (2005)

5. Cheeseman, C.: Proceedings of the Second International Slag Valorization Symposium, Leuven, Belgium, 18-20 April 2011

6. Wang, H.Y., Hsiao, D.H., Wang, S.Y.: Comput Concr 10(2), 95-104 (2012)

7. Monteiro, M.A., Raupp-Pereira, F., Ferreira, V.M., Labrincha, J.A., Dondi, M.: Conference on the use of recycled materials in building and structures, Barcelona, Spain, 9-11 November 2004

8. Cheeseman, C.R., Makinde, A., Bethanis, S.: Resour Conserv Recycl 43, 147-162 (2005)

9. Quijorna, N., Coz, A., Andrés, C., Cheeseman, R.: Resour Conserv Recycl 65, 1-10 (2012)

10. Mendes, M.R., Rocha, J.C., Riella, H.C.: Production of lightweight aggregates by pyro-expansion of residues. In: Proceedings of the 17th International Conference on Solid Waste Technology and Management, pp. 318-325. Philadelphia, USA (2001)

11. Van der Sloot, H.A., Wainwright, P.J., Cresswell, D.J.F.: The production of synthetic aggregate from a quarry waste using an innovative style rotary kiln. Waste Manag Res 20, 279-289 (2002)

12. Tay, J.H., Show, K.Y., Hong, S.Y.: Reuse of industrial sludge as construction aggregates. Water Sci Tech 44(10), 269-273 (2001)

13. Weinecke, M.H., Faulkner, B.P.: Production of lightweight aggregate from waste materials. Mining Eng 54(11), 39-43 (2002)

14. Pinto, S. Rosenbom, K., Machado, L., Correia, A.M.S., Labrincha, J.A., Ferreira, V.M.: Recycling of industrial wastes in lightweight aggregate production. In: Proceedings of REWAS, Madrid, Spain, 26-29 September 2004

15. Balgaranova, J., Petrov, A., Pavlova, L., Alexandrova, E.: Utilization of wastes from the coke-chemical production and sewage sludge as additives in the brick-clay. Water Air Soil Pollut 150, 103-111 (2003). http://dx.doi.org/10.1023/A:1026190417523

16. Zalygina, O.S., Barantseva, S.E.: The use of excess activated sludge from municipal sewage treatment works in production of construction ceramics. Glass Ceram 55, 164-167 (1998)

17. Gregorová, E., Pabst, W., Bohaãenko, I.: Characterization of different starch types for their application in ceramic processing. J Eur Ceram Soc 26, 1301-1309 (2006)
18. Demir, I.: Effect of organic residues addition on the technological properties of clay bricks. Waste Manag 28, 622-627 (2008)

19. Wiebusch, B., Seyfried, C.F.: Utilization of sewage sludge ashes in the brick and tile industry. Water Sci Technol 36(11), 251-258 (1997)

20. Jordan, M.M., Almendro-Candel, M.B., Romero, M., Rincon, J.M.: Application of sewage sludge in the manufacturing of ceramic tile bodies. Appl Clay Sci 30(34), 219-224 (2005)

21. Anderson, M., Skerratt, R.G., Thomas, J.P., Clay, S.D.: Case study involving using fluidised bed incinerator sludge ash as a partial substitute in brick manufacture. Water Sci Technol 34(37), 507-515 (1996)

22. Monzo, J., Paya, J., Borrachero, M.V., Corcoles, A.: Use of sewage sludge ash (SSA)-cement admixtures in mortars. Cem Concr Res 26(9), 1389-1398 (1996)

23. Khanbilvardi, R., Afshari, S.: Sludge ash as fine aggregate for concrete mix. J Environ Eng ASCE 121(9), 633-638 (1995)

24. Bhatty, J.I., Reid, K.J.: Compressive strength of municipal sludge ash mortars. ACI Mater J 86(4), 394-400 (1989)

25. Pan, S.H., Tseng, D.H., Lee, C.C., Lee, C.: Influence of the fineness of sewage sludge ash on the mortar properties. Cem Concr Res 33(11), 1749-1754 (2003)

26. Cusidó, J.A., Soriano, C.: Valorization of pellets from municipal WWTP sludge in lightweight clay ceramics. Waste Manag 31(6), 1372-1380 (2011)

27. Wang, X., Jin, Y., Wang, Z., Mahar, R.B., Nie, Y.: A research on sintering characteristics and mechanisms of dried sewage sludge. J Hazard Mater 160(2-3), 489-494 (2008)

28. Qui, Y., Yue, Q., Han, S., Yue, M., Gao, B., Yu, H., Shao, T. Preparation and mechanism of ultra lightweight ceramics produced from sewage sludge. J Hazard Mater 176, 76-84 (2010)

29. Chen, H.J., Yang, M.D., Tang, C.W., Wang, S.Y.: Producing synthetic lightweight aggregate from reservoir sediments. Constr Build Mater 28(1), 387-394 (2012)

30. Jordán, M.M., Martín-Martín, J.D., Sanfeliu, T., Gómez-Gras, D., Fuente, C.: Mineralogy firing transformations of Permo-Triassic clays used in the manufacturing of ceramic tile bodies. Appl Clay Sci 44(12), 173-179 (2009)

31. Elías, X.: Optimización de los Procesos Cerámicos Industriales,La cerámica como tecnología devalorización de residuosMedellín (2000). http://www.cnpml.org/html/archivos/ Ponencias (2001)

32. Mekki, H., Anderson, M., Benzina, M., Ammar, E.: Valorization of olive mill wastewater by its incorporation in building bricks. J Hazard Mater 158, 308-315 (2008)

33. Colomer, F.J., Gallardo, A., Robles, F., Bovea, D., Herrera, L.: Opciones de valorización de lodos de distintas estaciones depuradoras de aguas residuales. Ing 14(3), 177-190 (2010)

34. UNE 32006, Solid mineral fuels. Determination of gross calorific value by automatic calorimeter (1995)

35. NPR-CENT/TS 15359 EN. Solid recovered fuels-specifications and classes

36. UNE 67-027, Burned clay bricks. Determination of water absorption (1984)

37. Red Interinstitucional de TecnologíasLimpias. Grupo de Calculo UIS-IDEAM. http://www.Tecnologiaslimpias.org/html/central/ 369102/369102_rn.htm

38. Hartman, M., Svoboda, K., Pohorely, M., Trnka, O.: Combustion of dried sewage sludge in a fluidized-bed reactor. Ind Eng Chem Res 44, 3432-3441 (2005)

39. Colina, R., Primera, J., Plaza, E., Huerta, L.: Extracción con microondas de la materia orgánica presente en un gel de $\mathrm{SiO}_{2}$ sintetizados por la vía de los atranos. Ciencia 19(3), 223-230 (2011)

40. Neimark, A.V., Ravicovitch, P.I.: Capillary condensation in MMS and pore structure characterization. Microporous Mesoporous Mater 697, 44-45 (2001) 